\title{
Perbedaan Intensitas Nyeri Saat Tindakan Skeling Ultrasonik Berdasarkan Kriteria OHI-S di RSGM Universitas Sam Ratulangi
}

\author{
${ }^{1}$ Deborah Karamoy \\ ${ }^{2}$ Damajanty H. C. Pangemanan \\ ${ }^{1}$ Christy N. Mintjelungan \\ ${ }^{1}$ Johanna Khoman
}

\author{
${ }^{1}$ Program Studi Pendidikan Dokter Gigi Fakultas Kedokteran \\ ${ }^{2}$ Bagian Fisiologi Fakultas Kedokteran \\ Universitas Sam Ratulangi Manado \\ Email: deborahkaramoy11@gmail.com
}

\begin{abstract}
Pain is defined as an unpleasant sensory and emotional experience related to actual or the potential to cause tissue damage. Ultrasonic scaling is easier and more preferred to remove calculus on the tooth surface compared to manual scaling. The Oral Hygiene Index Simplified (OHI-S) is an index for assessing dental and oral hygiene status. This study was aimed to obtain the differences in pain intensity during ultrasonic scaling treatment among patients with varied OHI-S at RSGM Unsrat. This study is an analytical study using a cross sectional analysis. There were 36 patients involved in this study, obtained by using total sampling method. The results showed that the means of pain intensity during ultrasonic scaling in patients with good OHI-S was $6.50 \%$; in patients with moderate OHI-S was $18.50 \%$; and in patients with poor OHI-S was $28.79 \%$. The Kruskal Wallis test showed a pvalue of 0,000 for the differences in pain intensity during ultrasonic scaling. It is concluded that there were significant differences in the pain intensity during ultrasonic scaling based on the OHI-S criteria.
\end{abstract}

Keywords: pain, ultrasonic scaling, Oral Hygiene Index Simplified (OHI-S).

\begin{abstract}
Abstrak: Nyeri didefinisikan sebagai pengalaman sensorik dan emosional yang tidak menyenangkan berkaitan dengan kerusakan jaringan yang aktual atau berpotensi untuk mengakibatkan kerusakan jaringan. Skeling ultrasonik merupakan skeling yang lebih mudah dan lebih banyak dilakukan untuk menghilangkan kalkulus pada permukaan gigi dibanding dengan skeling manual. Oral Hygiene Index Simplified (OHI-S) merupakan indeks untuk menilai status kebersihan gigi dan mulut. Penelitian ini bertujuan untuk mengetahui perbedaan intensitas nyeri saat tindakan skeling ultrasonik berdasarkan kriteria OHI-S di RSGM Unsrat. Jenis penelitian ialah analitik dengan desain potong lintang. Sampel diperoleh secara total sampling yang berjumlah 36 orang. Hasil pemeriksaan menunjukkan nilai rerata intensitas nyeri saat skeling ultrasonik dengan OHI-S baik sebesar 6,50\%; dengan OHI-S sedang sebesar 18,50\%; dan dengan OHI-S buruk sebesar 28,79\%. Hasil uji Kruskal Wallis terhadap perbedaan nilai rerata intensitas myeri mendapatkan nilai $\mathrm{p}=0,000$. Simpulan penelitian ini ialah terdapat perbedaan bermakna dalam intensitas nyeri saat tindakan skeling ultrasonik berdasarkan kriteria OHI-S.
\end{abstract}

Kata kunci: nyeri, skeling ultrasonik, Oral Hygiene Index Simplified (OHI-S)

Nyeri merupakan salah satu alasan bagi seseorang untuk datang dan melakukan perawatan gigi dan mulut. Menurut Inter national Association for Study of Pain (IASP) nyeri didefinisikan sebagai pengalaman sensorik dan emosional yang tidak 
menyenangkan berkaitan dengan kerusakan jaringan yang aktual atau berpotensi untuk mengakibatkan kerusakan jaringan. ${ }^{1}$

Hasil Riset Kesehatan Dasar (Riskesdas) tahun 2018 menunjukkan prevalensi nasional masalah gigi dan mulut di Indonesia sebesar 57,6\%. Provinsi Sulawesi Utara merupakan salah satu provinsi dengan prevalensi masalah gigi dan mulut tertinggi ke empat di Indonesia. ${ }^{2}$

Kebersihan gigi dan mulut mempunyai peran yang sangat penting di bidang kesehatan gigi, karena kebersihan mulut yang buruk terhadap seseorang dapat mengakibatkan timbulnya berbagai penyakit baik lokal maupun sistemik. Secara klinis tingkat kebersihan mulut dinilai dengan kriteria Oral Hygiene Index Simplified (OHI-S). Kriteria ini dinilai berdasarkan keadaan endapan lunak (debris) dan karang gigi (kalkulus). ${ }^{3}$ Salah satu perawatan penyakit periodontal yaitu skeling, yang merupakan tindakan perawatan untuk menghilangkan plak, kalkulus, dan stain pada permukaan mahkota dan akar gigi. Dikenal dua metode skeling yaitu skeling manual dan skeling ultrasonik. ${ }^{4,5}$

Intensitas nyeri yang dialami saat skeling sulit untuk ditentukan karena setiap orang memiliki rasa nyeri yang berbedabeda. Umumnya skeling tidak terlalu menyakitkan, tetapi beberapa orang menganggap skeling sangat menyakitkan terutama yang penumpukan kalkulusnya cukup banyak. Perbedaan status mengenai intensitas nyeri saat skeling nantinya akan dapat membantu dokter gigi maupun pasien yang akan melakukan tindakan kedokteran gigi untuk dapat menangani rasa nyeri yang ditimbulkan akibat tindakan skeling. Bertolak dari hal tersebut, penulis melakukan penelitian mengenai perbedaan intensitas nyeri saat tindakan skeling ultrasonik berdasarkan kriteria OHI-S di Rumah Sakit Gigi dan Mulut Universitas Sam Ratulangi (RSGM Unsrat). Pengambilan subyek penelitian dilakukan di rumah sakit ini karena letaknya di tengah kota serta jumlah pasien skeling cukup banyak untuk diikutsertakan dalam penelitian.

\section{METODE PENELITIAN}

Jenis penelitian yang dilakukan ialah analitik dengan menggunakan desain potong lintang. Penelitian dilaksanakan pada bulan April-Mei 2019 di RSGM Unsrat Manado. Populasi penelitian ini yaitu pasien yang melakukan tindakan skeling ultrasonik di Bagian Periodonsia Rumah Sakit Gigi dan Mulut Universitas Sam Ratulangi. Metode pengambilan sampel yang digunakan ialah total sampling dan yang memenuhi kriteria inklusi berjumlah 36 orang.

Intensitas nyeri yang dimaksud dalam penelitian ini yaitu respon nyeri yang ditampilkan oleh seorang pasien saat dilakukan tindakan skeling dengan menggunakan skeler ultrasonic. Dilakukan pengukuran intensitas nyeri setelah dilakukan skeling dengan menggunakan Wong Baker Pain Rating Scale untuk menilai intensitas nyeri melalui ekspresi wajah yang terdiri dari enam bentuk ekspresi wajah dan diberi kode pada bentuk ekspresi wajah yang sesuai dengan penelitian.

Oral Hygiene Index Simplified (OHIS) digunakan untuk menilai status kebersihan gigi dan mulut. Penilaian skor OHI-S ialah sebagai berikut: Baik, bila nilai berada di antara $0-1,2$; sedang, bila nilai berada di antara 1,3-3,0; buruk bila nilai berada diantara $3,1-6,0{ }^{6}$

Instrumen dan alat penelitian yang digunakan dalam penelitian ini ialah lembar informed consent, lembar kuesioner, alat tulis, dan kamera.

Untuk mengetahui nilai OHI-S dari subyek, operator memeriksa langsung kebersihan rongga mulut pasien dan mencatat dalam rekam medik. Peneliti mengamati langsung ekspresi wajah saat subyek sedang dilakukan tindakan skeling ultrasonik yang sesuai dengan skala penelitian ini yaitu menggunakan Wong Baker Pain Rating Scale, kemudian diberi kode centang pada lembar penilaian.

Data penelitian ini diproses dengan editing, coding, dan entry dan dianalisis menggunakan Statistical Product and Service Solution (SPSS) 22. Analisis perbedaan intensitas nyeri saat tindakan 
skeling ultrasonik berdasarkan kriteria OHI-S di RSGM Unsrat menggunakan uji Kruskal Wallis.

\section{HASIL PENELITIAN}

Penelitian ini dilakukan di RSGM Unsrat yang menyelenggarakan pelayanan kesehatan gigi dan mulut sekaligus merupakan sarana Pendidikan Profesi Dokter Gigi yang dikelola oleh Program Studi Pendidikan Dokter Gigi Fakultas Kedok-teran Unsrat, yang menyediakan berbagai macam pelayanan perawatan gigi dan mulut. Rumah Sakit Gigi dan Mulut Unsrat beralamat di Jalan Dr. Sutomo No.3, Kelurahan Pinaesaan, Kecamatan Wenang, Provinsi Sulawesi Utara. Penelitian ini melibatkan 36 pasien sebagai subyek; jumlah yang berjenis kelamin laki-laki sama banyak dengan perempuan.

Tabel 1 memperlihatkan distribusi subyek penelitian berdasarkan usia. Yang terbanyak ialah subyek berusia 20-29 tahun $(36 \%)$ dan yang paling sedikit berusia $40-$ 49 tahun $(31 \%)$.
Tabel 2 memperlihatkan perbedaan intensitas nyeri saat tindakan skeling ultrasonik berdasarkan kriteria OHI-S di RSGM Unsrat. Secara keseluruhan, terlihat bahwa nilai rerata intensitas nyeri saat tindakan skeling ultrasonik dengan OHI-S baik sebesar $6,50 \%$. Nilai rerata intensitas nyeri saat tindakan skeling ultrasonik dengan OHI-S sedang sebesar 18,50\% dan untuk nilai rerata intensitas nyeri saat skeling ultrasonik dengan OHI-S buruk sebesar 28,79\%. Hasil uji Kruskal Wallis menunjukkan nilai asymp.sig 0,000 (asymp.sig <0,05) yang berarti terdapat perbedaan intensitas nyeri saat tindakan skeling ultrasonik berdasarkan kriteria OHI-S.

Tabel 1. Distribusi subyek berdasarkan usia

\begin{tabular}{ccc}
\hline Usia (tahun) & $\mathbf{n}$ & $\mathbf{\%}$ \\
\hline $20-29$ & 13 & 36 \\
$30-39$ & 12 & 33 \\
$40-49$ & 11 & 31 \\
Total & 36 & 100 \\
\hline
\end{tabular}

Tabel 2. Perbedaan intensitas nyeri saat tindakan skeling ultrasonik berdasarkan kriteria OHI-S di RSGM Unsrat

\begin{tabular}{lccccccc}
\hline \multirow{2}{*}{ Intensitas nyeri } & \multicolumn{3}{c}{ Kategori OHI-S } & \multirow{2}{*}{ N } & Mean & $\begin{array}{c}\text { Nilai } \\
\text { asymp.sig }\end{array}$ \\
\cline { 2 - 4 } & baik & sedang & buruk & & 0 & 0 & \\
Tidak nyeri & 0 & 0 & 0 & 0 & 0 & \\
Sedikit nyeri & 12 & 0 & 0 & 12 & 6,50 & \\
Sedikit lebih nyeri & 0 & 11 & 0 & 11 & 18,50 & \\
Lebih nyeri & 0 & 0 & 13 & 13 & 28,79 & $0,000^{*}$ \\
Sangat nyeri & 0 & 0 & 0 & 0 & 0 & \\
Nyeri sangat hebat & 0 & 0 & 0 & 0 & 0 & \\
Total & 12 & 11 & 13 & 36 & & \\
\hline
\end{tabular}

*Kruskal Wallis Test; Asymp.sig <0,05

\section{BAHASAN}

Penelitian ini dilakukan pada 36 pasien yang bertujuan untuk mengetahui perbedaan intensitas nyeri saat tindakan skeling ultrasonik berdasarkan kriteria OHI-S di RSGM Unsrat. Penilaian intensitas nyeri saat skeling ultrasonik dengan perbedaan OHI-S dilakukan pada saat pasien sedang mdiakukan skeling ultrasonik.
Pada penelitian ini, terdapat 18 pasien berjenis kelamin laki-laki dan 18 pasien berjenis kelamin perempuan (masingmasing 50\%). Dari rerata intensitas nyeri dengan perbedaan OHI-S berdasarkan jenis kelamin, didapatkan subyek laki-laki dengan intensitas nyeri kategori lebih nyeri sebesar $16,7 \%$ sedangkan pada subyek perempuan intensitas nyeri kategori lebih nyeri sebesar 
$19,4 \%$, yang menunjukkan terdapat perbedaan intensitas nyeri antara laki-laki dan perempuan. Intensitas nyeri pada perempuan lebih tinggi dibandingkan pada laki-laki. Hal ini didukung dengan penelitian Guzeldemir et $\mathrm{al}^{7}$ di Turki yang menyatakan bahwa terdapat hubungan antara jenis kelamin dengan intensitas nyeri. Demikian pula penelitian dari Yezierski yang melaporkan bahwa rasa nyeri saat perawatan dokter gigi lebih banyak terjadi pada perempuan. ${ }^{8}$ Penelitian dari Sanikop et al ${ }^{9}$ di India juga menyatakan bahwa perempuan lebih dapat mengekspresikan rasa nyeri dibandingkan laki-laki. Laki-laki cenderung menutupi rasa nyeri karena dianggap tidak maskulin. ${ }^{9}$

Hasil penelitian ini memperlihatkan bahwa intensitas nyeri dengan perbedaan OHI-S berdasarkan usia dari 36 subyek menunjukkan subyek berusia 20-29 tahun memiliki intensitas nyeri sebesar $19,4 \%$ dengan ketegori sedikit lebih nyeri; subyek berusia 30-39 tahun memiliki intensitas nyeri sebesar 13,9\%; sedangkan yang berusia 40-49 tahun memiliki intensitas lebih nyeri sebesar $19,4 \%$; hal ini menunjukkan seiring bertambahnya usia, maka semakin besar intensitas nyerinya. Hasil penelitian ini sesuai dengan penelitian Guzeldemir et $\mathrm{al}^{7}$ di Turki yang menyatakan bahwa terdapat perbedaan antara usia dan persepsi nyeri saat skeling. Hasil penelitian dari Saatchi et $\mathrm{al}^{10}$ di Iran melaporkan bahwa makin bertambah usia seseorang, maka fungsi organ juga akan menurun, salah satunya yaitu stimulus untuk merasakan nyeri.

Dari keenam kategori tersebut, hanya tiga kategori nyeri saja yang tampak pada pengamatan ekspresi wajah subyek yang diteliti, yaitu ekspresi wajah yang menandakan intensitas nyeri kategori sedikit nyeri, sedikit lebih nyeri, dan kategori lebih nyeri saat dilakukan skeling. Jumlah subyek pada kategori sedikit nyeri sebesar $33,3 \%$; sedikit lebih nyeri sebesar $30,6 \%$, dan lebih nyeri sebesar 36,1\%. Hal ini berarti intensitas nyeri katogeri lebih nyeri paling banyak dialami pada skeling ultrasonik pada subyek dengan OHI-S buruk dibandingkan dengan katogeri lainnya. Hal ini disebabkan oleh karena penumpukan kalkulus yang banyak akan menyebabkan rasa nyeri yang lebih akibat tindakan skeling ultrasonik tersebut.

Hasil penelitian ini memperlihatkan perbedaan intensitas nyeri saat tindakan skeling ultrasonik berdasarkan kriteria OHI-S di RSGM Unsrat. Secara keseluruhan, terlihat nilai rerata intensitas nyeri dengan OHI-S baik sebesar 6,50\%, OHI-S sedang 18,50\%, dan OHI-S buruk 28,79\%. Hal ini dapat menyimpulkan yaitu bahwa intensitas nyeri yang paling besar terjadi pada subyek dengan OHI-S buruk. Hasil penelitian ini juga didukung oleh penelitian oleh Sanikop et $\mathrm{al}^{9}$ yang menyatakan adanya nyeri saat skeling ultrasonik pada pasien dengan perbedaan tingkatan OHI-S. Pasien dengan OHI-S baik tetap akan merasakan nyeri, begitupun dengan OHI-S sedang dan OHI-S buruk tetapi dalam tingkatan yang berbeda.

Penyebab besarnya intensitas nyeri saat skeling ultrasonik dipengaruhi oleh beberapa faktor, yaitu getaran yang ditimbulkan oleh skeler dapat mengakibatkan rasa nyeri oleh tekanan yang digunakan saat skeling. Semakin buruk OHI-S atau semakin buruk kebersihan rongga mulut maka kalkulusnya akan semakin banyak yang dapat menyebabkan tekanan skeler yang berlebih. Penelitian ini juga didukung oleh penelitian yang dilakukan oleh Sanikop et al $^{9}$ yang menyatakan bahwa variasi tekanan yang dilakukan oleh operator pada ujung skeler ultrasonik untuk menghilangkan kalkulus menghasilkan variasi nyeri pada pasien. Panasnya skeler yang nantinya memengaruhi intensitas nyeri saat skeling. Semakin banyak kalkulus maka akan semakin lama alat skeler bekerja yang akan menyebabkan skeler lebih panas sehingga intensitas nyeri juga akan semakin bertambah. Selain itu, ketajaman dari instrumen dan kalkulus yang semakin banyak akan menyebabkan terjadi resesi gingiva. Penelitian Shaju et $\mathrm{al}^{11}$ menunjukkan terdapat perbedaan nyeri saat tindakan skeling dengan pemakaian alat skeling yang berbeda. OHI-S buruk 
membutuhkan waktu lebih lama untuk dilakukan prosedur skeling dan tekanan lebih banyak untuk menghilangkan kalkulus yang banyak tersebut.

Selain rasa nyeri yang ditimbulkan, skeling ultrasonik memiliki keuntungan dalam pembersihan karang gigi, seperti penggunaan waktu yang lebih efisien, lebih ergonomis, dan modifikasi desain dari ujung alat dapat meningkatkan akses untuk beberapa area termasuk furkasi. ${ }^{11}$ Hasil penelitian Shaju et $\mathrm{al}^{11}$ memperlihatkan bahwa skeling dengan menggunakan skeler ultrasonik membuat permukaan gigi yang telah diskeling lebih halus tanpa menghilangkan jaringan keras gigi. Pada ujung alat ultrasonik terdapat semprotan air yang bertujuan untuk menghilangkan panas yang umumnya terjadi akibat getaran ultrasonik, selain itu juga berfungsi sebagai pembersih permukaan gigi. Skeling ultrasonik telah terbukti efektif untuk menghilangkan kalkulus supragingiva dan plak subgingiva baik yang melekat maupun yang tidak melekat, serta menghilangkan toksin dari permukaan akar dan mengurangi kedalaman poket. ${ }^{12}$

\section{SIMPULAN}

Berdasarkan hasil penelitian ini dapat disimpulkan bahwa terdapat perbedaan bermakna pada intensitas nyeri saat tindakan skeling ultrasonik berdasarkan kriteria OHI-S.

Perlu dilakukan penelitian lanjut untuk melihat perbedaan intensitas nyeri saat tindakan skeling ultrasonik berdasarkan kriteria OHI-S menggunakan lokasi berbeda, misalnya di tempat praktik dokter gigi. Operator sebaiknya memberitahukan terlebih dahulu bahwa saat sedang melakukan tindakan skeling akan terasa nyeri.

\section{DAFTAR PUSTAKA}

1. Kumar KH, Elavarasi P. Definition of pain and classification of pain disorders. JCRI. 2016;3(3):87-8.
2. Badan Penelitian dan Pengembangan Kesehatan. Hasil Utama Riskesdas 2018. Jakarta: Kemenkes RI 2018; h. 93-6.

3. Basuni, Cholil, Putri D. Gambaran Indeks Kebersihan Mulut Bedasarkan Tingkat Pendidikan Masyarakat di Desa Guntung Ujung Kabupaten Banjar. Dentino. 2014;2(1):19.

4. Krismariono A. Prinsip-prinsip Dasar Scaling dan Root Planning dalam Perawatan Periodontal. Periodontic Journal. 2009; 1(1):30-4.

5. Nirola A, Batra P, Kaur S. Comparison of nonsurgical periodontal therapy with hand scaler, conventional ultrasonic scaler, and vector ultrasonic system in patients with generalized chronic periodontitis. Indian Journal of Dental Sciences 2016;8(4):226.

6. Herijulianti, E, Indriani TS, Artini S. Pendidikan Kesehatan Gigi. Jakarta: EGC, 2001; p, 101-8.

7. Guzeldemir E, Oygar U, Cilasun U. Pain perception and anxiety during scaling in periodontally healty subjects. J Periodontol. 2009;79:2247-55.

8. Yezierski RP. The effect on pain sensitivity: Preclinical Student. Pain Medicine 2012:13(2):27-36.

9. Sanikop S, Agrawal P, Patil S. Relationship between dental anxiety and pain perception during scaling. J Oral Sci. 2011;53(3):341-8.

10. Saatchi M, Abtahi M, Mohammadi G, Mirdamadi M, Binandeh E. The prevalence of dental anxiety and fear in patients referred to Isfaham dental school. Dental Res J. 2015;12(3):24853.

11. Shaju P, Amirishetty R, Zade M. Factors influencing pain experienced during scaling and root planing: A correlative pilot trial. J Periodonta Implant Dent. 2011;3:8-12.

12. Chatterjee A, Baiju S, Bose S, Shetty $S$. Clinical uses and benefits of ultrasonic scalers as compared to curetes: A review. J Oral Health \& Community Dent. 2013;7(2):108-13. 